\title{
Prevalence and antimicrobial resistance of Salmonella in chicken carcasses at retail in 15 Brazilian cities
}

\author{
Marcelo Augusto Nunes Medeiros, ${ }^{1}$ Diana Carmem Nunes de Oliveira, ${ }^{1}$ \\ Dália dos Prazeres Rodrigues, ${ }^{2}$ and Daniel Roberto Coradi de Freitas ${ }^{3}$
}

Suggested citation Medeiros MAN, Oliveira DCN, Rodrigues DP, Freitas DRC. Prevalence and antimicrobial resistance of Salmonella in chicken carcasses at retail in 15 Brazilian cities. Rev Panam Salud Publica. 2011; 30(6):555-60.

ABSTRACT Objective. To describe the prevalence and antimicrobial resistance of Salmonella spp. in frozen chicken carcasses at retail from 15 Brazilian cities.

Methods. A descriptive study of data from the Brazilian National Program for Monitoring the Prevalence of Bacterial Resistance in Chicken (PREBAF) was conducted from September 2004 to July 2006. The program collected chicken carcasses in 15 state capitals of Brazil in the five geographic regions of the country. Standardized methodologies were used to isolate Salmonella spp. and identify serotypes. The minimal inhibitory concentration method was used to test resistance to 18 antimicrobials.

Results. In 2679 carcasses examined, the prevalence of Salmonella spp. was $2.7 \%$ (range 0.0\%-8.9\%). São Paulo State produced $50.6 \%$ of positive samples. Eighteen serotypes were identified. The most frequently occurring were Salmonella Enteritidis (48.8\%), Salmonella Infantis (7.6\%), Salmonella Typhimurium (7.2\%), and Salmonella Heidelberg (6.4\%). All 250 strains tested were resistant to one or more antibiotics, and $133(53.2 \%)$ were multidrug resistant ( $\geq 3$ classes). S. Heidelberg was resistant to ceftriaxone ( $75.0 \%)$ and to ceftiofur $(43.8 \%)$.

Conclusions. The prevalence of Salmonella spp. found in this study was relatively low. However, there were a high proportion of multidrug-resistant strains, including thirdgeneration cephalosporins used to treat invasive salmonellosis. The results confirm the relevance of the PREBAF program. It is recommended that PREBAF be improved, including a timely data analysis. A review of permitted limits for Salmonella spp. in retail chicken in Brazil is also needed.

Key words Salmonella; drug resistance, microbial; chickens; food microbiology; health surveillance; Brazil.

Salmonella spp. are one of the most significant pathogens that affect the health

1 Agência Nacional de Vigilância Sanitária, Brasília, Brazil. Send correspondence to: Marcelo Augusto Nunes Medeiros, marcelo.medeiros@anvisa.gov.br

2 Fundação Oswaldo Cruz, Laboratório de Referência Nacional de Cólera e Enteroinfecções Bacterianas, Rio de Janeiro, Brazil.

3 Universidade de Brasília, Núcleo de Medicina Tropical, Brasília, Brazil. of populations (1). In Brazil, from 1999 to 2008, there were 6602 outbreaks of foodborne diseases, and Salmonella spp. was present in $43 \%$ of the outbreaks in which the etiologic agent was identified (2). Although the genus is composed of several serotypes, only a few predominate in human disease epidemiology: Typhimurium, Hadar, Heidelberg, Infantis, and Enteritidis (3, 4). Because salmonella typically is found in poultry, this type of meat has been an important vehicle in foodborne diseases (1). In Brazil, chicken is widely consumed (5) and is mostly sold as frozen carcasses (6).

Chicken farms widely use antimicrobials as a prophylactic and a growth stimulant. Extensive antibiotic use and subtherapeutic doses in the diet can contribute to increased prevalence of 
multidrug-resistant bacteria in human and veterinary medicine (7). These bacteria can spread through the food chain and a pool of resistance genes can be transferred to human pathogens, reducing the availability of effective molecules to treat infectious diseases caused by these agents (8).

The increasing isolation of Salmonella spp. with antimicrobial resistance in humans and other animals is a public health problem (9). Some studies using pulsedfield gel electrophoresis suggested that chicken can be a source of antimicrobialresistant Salmonella spp. in humans (10, 11). Multidrug-resistant Salmonella spp. in chicken and the presence of bla(CMY) genes, responsible for plasmid-mediated resistance to ceftiofur and ceftriaxone (11), have been demonstrated.

Because of a lack of studies at the national level in Brazil to assess the prevalence and antimicrobial resistance of Salmonella spp. in poultry, the National Health Surveillance Agency (Agência National de Vigilância Sanitária) conducted the Brazilian National Program for Monitoring the Prevalence of Bacterial Resistance in Chicken (PREBAF) (Programa Nacional de Monitoramento da Prevalência da Resistência Bacteriana em Frango) from 2004 to 2006. This study uses PREBAF data to describe bacterial resistance and the prevalence of Salmonella spp.

\section{MATERIALS AND METHODS}

A descriptive study was conducted of the prevalence and resistance of Salmonella spp. to antimicrobials isolated from frozen chicken carcasses at retail in Brazil. The sample collection period was September 2004 to July 2006.

The number of carcasses to be collected was determined by PREBAF and was based on simple random sampling of an infinite population of frozen chicken carcasses (12). The parameters set were an expected prevalence of $10.0 \%$, a confidence level of $90.0 \%$, and an absolute margin of error of $1.0 \%$, resulting in a minimum sample of 2429 units.

The samples were collected by the state or municipality Departments of Health Surveillance (Vigilâncias Sanitárias) (VISA) and Salmonella spp. were isolated by the Central Public Health Laboratories (Laboratórios Centrais de Saúde Pública) (LA$\mathrm{CEN}$ ). Fifteen state capitals were included and were spread throughout the five Brazilian geographic regions (Figure 1). Cities were selected on the basis of their operational capacity, the interest of their VISA and LACEN to participate in the study, and their geographic location, so that all five regions were included. Collection of 10 samples per month from local retailers in each city was recommended and consisted of two sets of different brands. Each set contained five units with the same lot number, production date, and expiration date. Selection of brands was based on market availability, prioritizing carcasses processed locally. No selection criteria for retailers were defined. Samples were stored at freezing temperatures, without seasoning, for at least 60 days after the expiration date, with no evidence of violations in the primary container, tampering, or deterioration. Each VISA transported the samples from the retail location to the LACEN in up to 72 hours, keeping them frozen.

Salmonella spp. was detected after the carcasses were rinsed (13); the presence of bacteria was assessed in a portion of $25 \mathrm{~g}$ of chicken for determining the most probable number of Salmonella spp. (14), with a most probable number detection limit of 0.036 per gram of Salmonella spp. For strain identification and analysis of antimicrobial susceptibility, isolates were sent to the Oswaldo Cruz Institute; international standards were followed. The strains were reisolated according to the method of preservation. Genus and species were characterized through confirmation of cultures, when the profiles were consistent with Salmonella spp.

Antimicrobial resistance was evaluated by determining the minimum inhibitory concentration by microdilution, based on standard methodology (15). Eighteen antimicrobials (seven classes) were used: $\beta$-lactams, fenicols, tetracy-

FIGURE 1. Locations (city and state) of collection of chicken carcasses, Brazil, 2004-2006

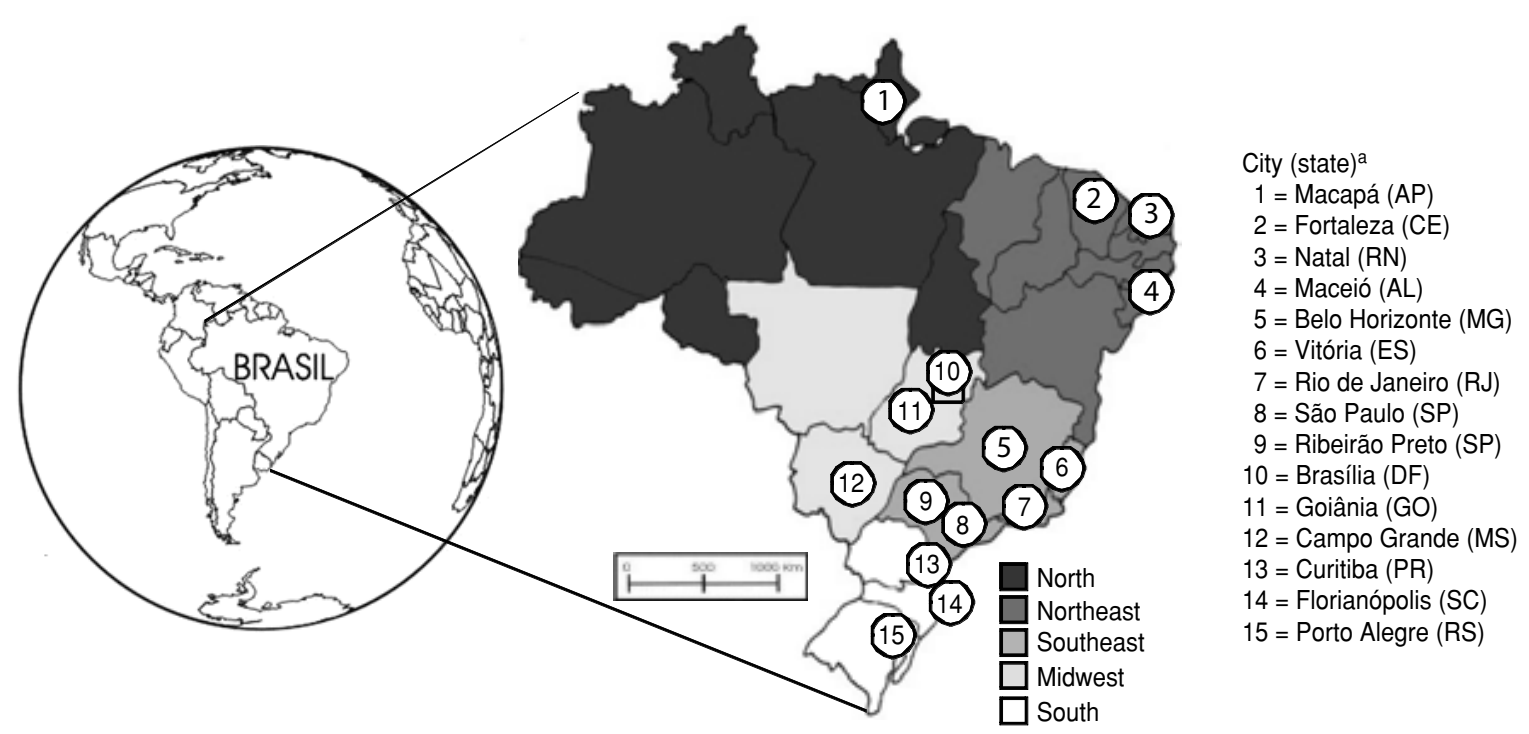

a AP: Amapá, CE: Ceará, RN: Rio Grande do Norte, AL: Alagoas, MG: Minas Gerais, ES: Espírito Santo, RJ: Rio de Janeiro, SP: São Paulo, DF: Distrito Federal, GO: Goiás, MS: Mato Grosso do Sul, PR: Paraná, SC: Santa Catarina, RS: Rio Grande do Sul. 
clines, quinolones, aminoglycosides, nitrofurans, and antifolates (Table 1). The criterion of choice was based on antimicrobials for veterinary and human use as directed by the World Health Organization. To control quality of performance and reliability of results, standard strains (Escherichia coli ATCC 25922, E. coli ATCC 35218, Pseudomonas aeruginosa ATCC 27853, Enterococcus faecalis ATCC 29212, and Staphylococcus aureus ATCC 25923) were tested under the same culture conditions.

The databank was analyzed with Microsoft Excel and Epi Info ${ }^{\mathrm{TM}}$ 3.5.1.

\section{RESULTS}

A total of 2679 carcasses were collected and surveyed for the presence of Salmonella spp. in 15 cities. Samples were irregularly distributed, unlike the recommended method. Seventy-three samples were infected with Salmonella spp., resulting in a $2.7 \%$ national prevalence, ranging from $0.0 \%$ in Vitória to $8.9 \%$ in São Paulo (Table 2).

Five states (Paraná, São Paulo, Minas Gerais, Rio Grande do Sul, and Santa Catarina) produced $72.4 \%$ of the carcasses sampled. The prevalence of Salmonella spp. in the 505 carcasses produced in the state of São Paulo was 7.3\%, which represents $50.6 \%$ of positive carcasses collected at retail from the 15 state capitals (Table 3).

TABLE 1. Antimicrobials used in determining minimum inhibitory concentration, Brazil, 2004-2006

\begin{tabular}{|c|c|}
\hline Class & Antimicrobial \\
\hline \multicolumn{2}{|l|}{$\beta$-Lactam } \\
\hline Penicillin & Ampicillin \\
\hline Monobactamic & Aztreonam \\
\hline \multirow[t]{4}{*}{ Cephalosporin } & Cephalotin \\
\hline & Cefoxitine \\
\hline & Ceftriaxone \\
\hline & Ceftiofur \\
\hline \multirow[t]{2}{*}{ Fenicol } & Florfenicol \\
\hline & Chloramphenicol \\
\hline \multirow[t]{2}{*}{ Aminoglycoside } & Streptomycin \\
\hline & Gentamicin \\
\hline \multirow[t]{3}{*}{ Quinolone } & Nalidixic acid \\
\hline & Ciprofloxacin \\
\hline & Enrofloxacin \\
\hline Tetracycline & Tetracycline \\
\hline \multirow[t]{3}{*}{ Antifolate } & Sulfonamide \\
\hline & Trimethoprim \\
\hline & Trimethoprim-sulfamethoxazole \\
\hline Nitrofuran & Nitrofurantoin \\
\hline
\end{tabular}

TABLE 2. Number of carcasses collected and prevalence of Salmonella spp. in 15 state capitals, Brazil, 2004-2006

\begin{tabular}{lccc}
\hline & & \multicolumn{2}{c}{ Salmonella positive } \\
\cline { 3 - 4 } \multicolumn{1}{c}{ City } & carcasses & No. & $\%$ \\
\hline Macapá & 195 & 6 & 3.1 \\
Fortaleza & 180 & 4 & 2.2 \\
Natal & 180 & 5 & 2.8 \\
Maceió & 180 & 5 & 2.8 \\
Belo Horizonte & 180 & 3 & 1.7 \\
Vitória & 135 & 0 & 0.0 \\
Rio de Janeiro & 190 & 4 & 2.1 \\
São Paulo & 180 & 16 & 8.9 \\
Ribeirão Preto & 180 & 11 & 6.1 \\
Brasília & 169 & 3 & 1.8 \\
Goiânia & 180 & 1 & 0.6 \\
Campo Grande & 190 & 5 & 2.6 \\
Curitiba & 180 & 2 & 1.1 \\
Florianópolis & 180 & 1 & 0.5 \\
Porto Alegre & 180 & 7 & 3.8 \\
Total & 2679 & 73 & 2.7 \\
\hline
\end{tabular}

Two hundred and fifty strains were isolated; in $6.0 \%$ of them, it was not possible to complete antigenic characterization. Eighteen serotypes were identified. The most common were Salmonella Enteritidis (48.8\%), Infantis (7.6\%), Typhimurium (7.2\%), and Heidelberg (6.4\%). All strains were resistant to at least one class of antimicrobial and $53.2 \%$ showed multidrug resistance to three or more classes. Serotypes Heidelberg $(100 \%)$ and Enteritidis (63.9\%) showed the highest percentage of multiresistant strains (Table 4). Streptomycin $(89.2 \%)$, sulfonamides $(72.4 \%)$, florfenicol (59.2\%), and ampicillin $(44.8 \%)$ were the antimicrobials with the highest resistance rates (18 tested). Serotype Enteritidis showed resistance to all drugs tested and Heidelberg was resistant to ceftriaxone $(75.0 \%)$ and ceftiofur (43.8\%) (Table 5).

\section{DISCUSSION}

This study is the first in Brazil that shows, with national coverage, an estimated prevalence of Salmonella spp. in frozen chicken carcasses at retail and the antimicrobial resistance of the isolates. The prevalence of Salmonella spp. was relatively low. In other countries, prevalence rates can vary-for example, from $13.0 \%$ to $88.2 \%(16,17)$. Likewise, there are large differences in the prevalence of Salmonella spp. in studies conducted in Brazilian cities, which can range from $9.6 \%$ to $42.0 \%(18,19)$. These other studies used chilled carcasses but PREBAF included only frozen carcasses. The prevalence of Salmonella found in PREBAF was lower than in the other studies and may be due to the difficulty of recovering Salmonella spp. from frozen carcasses, as freezing may damage bacteria such as Salmonella spp. (20).

Compared with other studies that evaluated frozen carcasses, the prevalence of Salmonella spp. in this study was similar to the $2.5 \%$ found in 116 carcasses ready for retail distribution in the state of São Paulo (21). Yet, it is more than 10 times lower than the $32.0 \%$ found in 150 carcasses at retail in Jaboticabal city, São Paulo (22). The prevalence of Salmonella spp. is expected to vary in different brands of chicken. Since the Jaboticabal survey sampled only four brands of chicken, there is a greater likelihood that, by chance, this study sampled only the brands with a high prevalence of Salmonella spp. and that the prevalence in this city was overestimated. PREBAF sampled dozens of brands in 15 cities (results not shown).

In the city of São Paulo, the prevalence of Salmonella spp. in chicken was about

TABLE 3. Number of carcasses collected at retail from 15 state capitals, by state of production, Brazil, 2004-2006

\begin{tabular}{|c|c|c|c|c|c|}
\hline \multirow[b]{3}{*}{ State } & \multirow{2}{*}{\multicolumn{2}{|c|}{$\begin{array}{c}\text { Carcasses } \\
\text { collected } \\
n=2679\end{array}$}} & \multicolumn{3}{|c|}{ Salmonella positive } \\
\hline & & & \multirow[b]{2}{*}{ No. } & \multirow{2}{*}{$\begin{array}{l}\% \text { in each } \\
\text { producing } \\
\text { state }\end{array}$} & \multirow{2}{*}{$\begin{array}{c}\% \text { in positive } \\
\text { samples } \\
\text { nationwide } \\
n=73\end{array}$} \\
\hline & No. & $\%$ & & & \\
\hline Paraná & 629 & 23.5 & 5 & 0.8 & 6.8 \\
\hline São Paulo & 505 & 18.9 & 37 & 7.3 & 50.6 \\
\hline Minas Gerais & 320 & 11.9 & 3 & 0.9 & 4.1 \\
\hline Rio Grande do Sul & 245 & 9.1 & 7 & 2.9 & 9.6 \\
\hline Santa Catarina & 240 & 9.0 & 1 & 0.4 & 1.4 \\
\hline Othera & 740 & 27.6 & 20 & 2.7 & 27.4 \\
\hline
\end{tabular}

Grosso do Sul, Pará, Pernambuco, Rio de Janeiro, and Rio Grande do Norte. 
TABLE 4. Salmonella spp. serotypes identified, number of strains, and antimicrobial resistance in number of classes, Brazil, 2004-2006

\begin{tabular}{|c|c|c|c|c|c|c|}
\hline \multirow[b]{3}{*}{ Salmonella serotype } & \multirow{2}{*}{\multicolumn{2}{|c|}{ Strain }} & \multicolumn{4}{|c|}{ Classes with antimicrobial resistance } \\
\hline & & & \multicolumn{2}{|c|}{1 or 2} & \multicolumn{2}{|c|}{$\geq 3^{\mathrm{a}}$} \\
\hline & No. & $\%$ & No. & $\%$ & No. & $\%$ \\
\hline Enteritidis & 122 & 48.8 & 44 & 36.1 & 78 & 63.9 \\
\hline Infantis & 19 & 7.6 & 11 & 57.8 & 8 & 42.1 \\
\hline Typhimurium & 18 & 7.2 & 10 & 55.6 & 8 & 44.4 \\
\hline Heidelberg & 16 & 6.4 & 0 & 0.0 & 16 & 100.0 \\
\hline Mbandaka & 12 & 4.8 & 7 & 58.3 & 5 & 41.7 \\
\hline Agona & 9 & 3.6 & 9 & 100.0 & 0 & 0.0 \\
\hline Rissen & 8 & 3.2 & 6 & 75.0 & 2 & 25.0 \\
\hline Give & 5 & 2.0 & 2 & 40.0 & 3 & 60.0 \\
\hline Panama & 5 & 2.0 & 5 & 100.0 & 0 & 0.0 \\
\hline Schwarzengrund & 3 & 1.2 & 0 & 0.0 & 3 & 100.0 \\
\hline Senftenberg & 3 & 1.2 & 3 & 100.0 & 0 & 0.0 \\
\hline Minnesota & 3 & 1.2 & 1 & 33.3 & 2 & 66.7 \\
\hline Saintpaul & 3 & 1.2 & 3 & 100.0 & 0 & 0.0 \\
\hline Ohio & 3 & 1.2 & 3 & 100.0 & 0 & 0.0 \\
\hline Lexington & 2 & 0.8 & 0 & 0.0 & 2 & 100.0 \\
\hline Newport & 2 & 0.8 & 2 & 100.0 & 0 & 0.0 \\
\hline Gaminara & 1 & 0.4 & 1 & 100.0 & 0 & 0.0 \\
\hline Rubislaw & 1 & 0.4 & 1 & 100.0 & 0 & 0.0 \\
\hline Salmonella spp..$^{b}$ & 15 & 6.0 & 9 & 60.0 & 6 & 40.0 \\
\hline Total & 250 & 100.0 & 117 & 46.8 & 133 & 53.2 \\
\hline
\end{tabular}

a Multidrug resistant.

b Serotype not identified.

TABLE 5. Antimicrobial resistance of the most common Salmonella spp. serotypes found in the sample, Brazil, 2004-2006

\begin{tabular}{|c|c|c|c|c|c|}
\hline \multirow[b]{2}{*}{ Antimicrobial } & \multicolumn{5}{|c|}{$\%$ resistant strains } \\
\hline & $\begin{array}{c}\text { Total } \\
(N=250)\end{array}$ & $\begin{array}{l}\text { Serotype } \\
\text { Enteritidis } \\
(n=122)\end{array}$ & $\begin{array}{l}\text { Serotype } \\
\text { Infantis } \\
(n=19)\end{array}$ & $\begin{array}{c}\text { Serotype } \\
\text { Typhimurium } \\
(n=18)\end{array}$ & $\begin{array}{c}\text { Serotype } \\
\text { Heidelberg } \\
(n=16)\end{array}$ \\
\hline Ampicillin & 38.0 & 25.4 & 31.6 & 83.3 & 100.0 \\
\hline Aztreonam & 19.2 & 9.0 & 15.8 & 50.0 & 87.5 \\
\hline Cephalotin & 12.0 & 12.3 & 0.0 & 0.0 & 81.3 \\
\hline Cefoxitine & 13.2 & 22.1 & 0.0 & 0.0 & 25.0 \\
\hline Ceftriaxone & 6.0 & 0.8 & 0.0 & 0.0 & 75.0 \\
\hline Ceftiofur & 28.0 & 27.9 & 31.6 & 11.1 & 43.8 \\
\hline Florfenicol & 62.0 & 67.2 & 36.8 & 61.1 & 100.0 \\
\hline Chloramphenicol & 6.0 & 12.3 & 0.0 & 0.0 & 0.0 \\
\hline Streptomycin & 78.0 & 64.8 & 94.7 & 100.0 & 100.0 \\
\hline Gentamicin & 12.0 & 13.9 & 26.3 & 11.1 & 0.0 \\
\hline Nalidixic acid & 40.0 & 63.9 & 15.8 & 11.1 & 12.5 \\
\hline Ciprofloxacin & 4.0 & 7.4 & 0.0 & 0.0 & 0.0 \\
\hline Enrofloxacin & 19.2 & 27.9 & 0.0 & 5.6 & 0.0 \\
\hline Tetracycline & 12.0 & 10.7 & 0.0 & 38.9 & 0.0 \\
\hline Sulfonamide & 58.0 & 54.1 & 94.7 & 50.0 & 100.0 \\
\hline Trimethoprim & 10.0 & 1.6 & 10.5 & 27.8 & 0.0 \\
\hline Trimethoprim-sulfamethoxazole & 10.0 & 3.3 & 10.5 & 27.8 & 0.0 \\
\hline Nitrofurantoin & 8.0 & 10.7 & 0.0 & 0.0 & 0.0 \\
\hline
\end{tabular}

three times higher than the national average. The variation in the prevalence at retail among cities in PREBAF may be explained by the fact that each city is supplied by several brands, with different levels of contamination. There were differences in the percentage of carcasses contaminated with Salmonella spp. among the producing states, and more than half of the contaminated samples were produced in the state of São Paulo. Carcasses produced in the state of São Paulo were collected at retail in all the cities surveyed except Florianópolis (results not shown), which showed a prevalence of Salmonella spp. below the national average. The systematic collection of carcasses provided a preferential collection of brands produced in the same state and may have contributed to the higher prevalence of Salmonella spp. found in retail in the cities of São Paulo and Ribeirão Preto in São Paulo State.

The most common serotypes in carcasses surveyed were the main serotypes of Salmonella found in the literature associated with disease in humans $(3,4)$. Salmonella serotype Enteritidis was the most frequent and occurred in nearly half of the contaminated samples. In the United States of America between 2000 and 2005, a significant increase was reported in the isolation of Enteritidis in chicken carcasses (23). In Brazil, other studies also found a predominance of this serotype $(18,19,22)$. In the late 1980s, Enteritidis caused a worldwide increase in the number of cases of human infections, mainly related to consumption of chicken (24).

All strains tested were resistant to one or more classes of antimicrobial agents and more than half were resistant to three or more classes. Serotype Enteritidis was resistant to all drugs in varying degrees. All Heidelberg strains showed multidrug resistance. This serotype had the highest percentages of resistance to ceftriaxone and ceftiofur, a third-generation cephalosporin used to treat human invasive salmonellosis. In the United States in 1997, strains of human origin were sensitive to cephalosporins, while only $1.6 \%$ of strains of avian origin were resistant to ceftiofur. Since 2003 , resistance to ceftiofur increased to $5.2 \%$ and $7.4 \%$ among strains isolated from humans and poultry, respectively, and susceptibility to ceftriaxone declined (25). In Brazil, the development of resistance in Salmonella spp. in chickens has been reported for at least 10 years (26) as has the presence of resistant isolates in different foods involved in outbreaks of salmonellosis (27). The results suggest that a resistant clonal group of serotype Enteritidis has been distributed recently in poultry, food, and human isolates in southern Brazil (28).

Monitoring data on Salmonella serotypes and resistance patterns circulating in the country must be evaluated on an ongoing basis and with support for revisions to define the limits of Salmonella spp. in poultry meat at retail in 
order to protect the health of the population. It has been shown that the circulation of multidrug-resistant serotypes of Salmonella spp. is associated with increased hospitalizations, mortality, and economic costs when compared with susceptible strains (29, 30). Although Brazilian legislation requires the absence of Salmonella spp. in a sample of $25 \mathrm{~g}$ of fresh meat from mammals at retail, it lacks the same requirement for birds (31). Simultaneously, in an attempt to reduce the risk associated with consumption of this food, there is a requirement to include labels with instructions on adequate preparation and conservation of this type of meat (32). Nevertheless, a study based on PREBAF data showed that $60 \%$ of the labels in São Paulo State were at odds with this requirement (33). It is noteworthy that, regardless of the adequacy of the labels, there are no studies that evaluate the effectiveness of this measure and its real impact on attitudes, perceptions, and behavior of consumers to protect their own health.

For evaluation of the results presented in this study, it should be considered that the criterion for selection of the retail suppliers was convenience and the sampling units were collected systematically and not randomly. Brazil is a country of continental dimensions, with producers of chicken in all its regions. PREBAF sampled dozens of brands (re- sults not shown) but the proportion of each brand in the total sample was not evaluated. It is expected that different brands are under different types of management and that there are different risks regarding the prevalence of Salmonella spp. and the use of antimicrobials. In addition, because the sampling did not consider the size of the population in each city where samples were collected, the samples are not in proportion to the chicken market or to domestic consumption. Thus, although collection covered the majority of state capitals, distributed in five regions of the country, it is not possible to extrapolate the results to a population of carcasses in the country.

Despite these limitations, this analysis of the first phase of PREBAF demonstrates a relatively low prevalence of Salmonella spp. However, the high incidence of multidrug resistance, especially in serotypes Enteritidis and Heidelberg, is a cause for concern among public health officials. These results show the importance of PREBAF and reinforce the need for continuing evaluation of the risk of antimicrobial resistance spread in chicken in Brazil.

Thus, to improve PREBAF in a second phase, the following suggestions are presented: (a) revise calculation of the sample based on the prevalence found in this study; (b) fix the methods of sampling, considering the representativeness of the sample in each city and the establishment of random criteria and a collection schedule; (c) evaluate other microorganisms in the monitoring program, given their occurrence in the poultry production chain and relevance in public health as well as microbiological risk to the spread of antimicrobial resistance (pathogens or not); (d) evaluate major Brazilian cities not sampled in the first phase of the program; (e) incorporate molecular subtyping tools, such as pulsed-field gel electrophoresis, to characterize and track multidrug-resistant clones circulating in the country; and (f) evaluate data generated by the monitoring program each month for appropriate measures to protect the health of the population. Further studies might be necessary to assess molecular correspondence between Salmonella spp. profiles found in PREBAF with sporadic cases and outbreaks of salmonellosis in humans.

Acknowledgments. The authors are grateful to the Central Public Health Laboratories for carcass collection and the Health Surveillance Centers for investigation of Salmonella spp. The authors thank Lígia Lindner Schreiner, Paula Roberta Mendes, Greice Madeleine Ikeda do Carmo, and Lucia Helena Berto for sharing their experiences and Suely Hiromi Tuboi for many helpful comments on the original manuscript.

\section{REFERENCES}

1. World Health Organization, Food and Agriculture Organization of the United Nations. Risk assessments of Salmonella in eggs and broiler chickens. Series no. 2, Geneva: WHO; 2002. P. 328. Available from: http://www. fao.org/DOCREP/005/Y4392E/y4392e00. htm Accessed 27 January 2011.

2. Ministério da Saúde, Secretaria de Vigilância em Saúde, Coordenação de Vigilância das Doenças de Transmissão Hídrica e Alimentar. Análise epidemiológica dos surtos de doenças transmitidas por alimentos no Brasil. Brasilia: Ministério da Saúde, Secretaria de Vigilância em Saúde, Coordenação de Vigilância das Doenças de Transmissão Hídrica e Alimentar; 2008. Available from: http://portal.saude. gov.br/portal/arquivos/pdf/surtos_dta_15. pdf Accessed 27 January 2011.

3. Khakhria R, Woodward WM, Johnson WM, Poppe C. Salmonella isolated from humans, animals and other sources in Canada, 198392. Epidemiol Infect. 1997;119(1):15-23.

4. Velge P, Cloeckaert A, Barrow P. Emergence of Salmonella epidemics: the problems related to Salmonella enterica serotype Enteritidis and multiple antibiotic resistance in other major serotypes. Vet Res. 2005;36(3):267-88.

5. União Brasileira de Avicultura. Relatório anual, 2009-2010. São Paulo: União Brasileira de Avicultura; 2010. Available from: http://www. brazilianchicken.com.br/publicacoes/relatorioanual-2010.pdf Accessed 27 January 2011.

6. Kume $\mathrm{H}$, Anderson $\mathrm{P}$, Oliveira M Jr. Identificação das barreiras ao comércio no mercosul: a percepção das empresas exportadoras brasileiras. Planejamento Políticas Públicas. 2001;23:165-204. Available from: http:// www.ipea.gov.br/ppp/index.php/PPP/ article/view/75/85 Accessed 27 January 2011.

7. Pessanha RP, Gontijo Filho PP. Uso de antimicrobianos como promotores de crescimento e resistência em isolados de Escherichia coli e de Enterobacteriaceae lactose-negativa da microflora fecal de frangos de corte. Arq Bras Med Vet Zootec. 2001;53(1):111-5.

8. Hasman H, Mevius D, Veldman K, Olesen I, Aarestrup FM. $\beta$-lactamases among extended-spectrum- $\beta$-lactamase (ESBL)resistant Salmonella from poultry, poul- try products and human patients in the Netherlands. J Antimicrob Chemother. 2005; 56:115-21.

9. Varma JK, Molbak K, Barrett TJ, Beebe JL, Jones TF, Rabatsky-Ehr T, et al. Antimicrobialresistant nontyphoidal Salmonella is associated with excess bloodstream infections and hospitalizations. J Infect Dis. 2005;191(4):554-61.

10. Kang ZW, Jung JH, Kim SH, Lee BK, Lee DY, Kim YJ, et al. Genotypic and phenotypic diversity of Salmonella Enteritidis isolated from chickens and humans in Korea. J Vet Med Sci. 2009;71(11):1433-8.

11. M'ikanatha NM, Sandt $\mathrm{CH}$, Localio AR, Tewari D, Rankin SC, Whichard JM, et al. Multidrug-resistant Salmonella isolates from retail chicken meat compared with human clinical isolates. Foodborne Pathog Dis. 2010;7(8):929-34.

12. Franklin A, Acar J, Anthony F, Gupta R, Nicholls T, Tamura Y, et al. Antimicrobial resistance: harmonization of national antimicrobial resistance monitoring and surveillance programmes in animals and in animal-derived food. Rev Sci Tech. 2001;20(3):859-70. 
13. Andrews WH, Hammack TS. BAM: food sampling/preparation of sample homogenate. In: Bacteriological analytical manual. 8th ed. Chapter 1. Rockville, Maryland: Food and Drug Administration; 2003. Available from: http:/ / www.cfsan.fda.gov/ ebam/bam-1. html Accessed 27 January 2011.

14. Blodgett R. Most probable number from serial dilutions. In: Bacteriological analytical manual. 8th ed. Appendix 2. Rockville, Maryland: Food and Drug Administration; 2003. Available from: http://www.cfsan.fda. gov/ ebam/bam-5.html Accessed 27 January 2011.

15. Clinical and Laboratory Standards Institute. Performance standards for antimicrobial susceptibility testing. Informational supplement. NCCLS document M31-S1. Wayne, Pennsylvania: Clinical and Laboratory Standards Institute; 2004.

16. Mikolajczyk A, Radkowski M. Salmonella spp. on chicken carcasses in processing plants in Poland. J Food Prot. 2002;65(9):1475-9.

17. Lay KS, Vuthy Y, Song P, Phol K, Sarthou JL. Prevalence, numbers and antimicrobial susceptibilities of Salmonella serovars and Campylobacter spp. in retail poultry in Phnom Penh, Cambodia. J Vet Med Sci. 2011;73(3)325-9.

18. Duarte DAM, Ribeiro AR, Vasconcelos AMM, Santos SB, Silva JVD, Andrade PLA, et al. Occurrence of Salmonella spp. in broiler chicken carcasses and their susceptibility to antimicrobial agents. Braz J Microbiol. 2009;40(3):569-73.

19. Fuzihara TO, Fernandes SA, Franco BD. Prevalence and dissemination of Salmonella serotypes along the slaughtering process in Brazilian small poultry slaughterhouses. J Food Prot. 2000;63(12):1749-53.

20. Vieira VR, Nascimento VP, Borsoi A, Santos LR. Efeito do congelamento na contagem de Salmonella enteritidis pelo método do número mais provável (NMP) em cecos de frangos de corte. Rev FZVA. 2007;14(2):140-7.

21. Tessari ENC, Cardoso ALSP, Kanashiro AMI, Stoppa GFZ, Luciano RL, de Castro AGM. Ocorrência de Salmonella spp. em carcaças de frangos industrialmente processadas, procedentes de explorações industriais do Estado de São Paulo, Brasil. Ciencia Rural. 2008;38(9):2557-60.

22. Santos DMS, Berchieri A Jr, Fernandes SA, Tavechio AT, Amaral LA. Salmonella em carcaças de frango congeladas. Pesq Vet Bras. 2000;20(1):39-42.

23. Altekruse SF, Bauer N, Chanlongbutra A, DeSagun R, Naugle A, Schlosser W, et al. Salmonella Enteritidis in broiler chickens, United States, 2000-2005. Emerg Infect Dis. 2006;12(12):1848-52.

24. Rodrigue DC, Tauxe RV, Rowe B. International increase in Salmonella Enteritidis: a new pandemic? Epidemiol Infect. 1990;105(1):21-7.

25. Food and Drug Administration. National Antimicrobial Resistance Monitoring Systementeric bacteria (NARMS): 2003 executive report. Rockville, Maryland: Food and Drug Administration; 2006.

26. Baú AC, Carvalhal JB, Aleixo JAG. Prevalência de Salmonella em produtos de frangos e ovos de galinha comercializados em Pelotas, RS, Brasil. Ciência Rural. 2001;31(2):303-7.

27. de Oliveira FA, Brandelli A, Tondo EC. Antimicrobial resistance in Salmonella Enteritidis from foods involved in human salmonellosis outbreaks in southern Brazil. New Microbiol. 2006;29(1):49-54.

28. Vaz CS, Streck AF, Michael GB, Marks FS, Rodrigues DP, Dos Reis EM, et al. Antimicrobial resistance and subtyping of Salmonella enterica subspecies enterica serovar Enteritidis isolated from human outbreaks and poultry in southern Brazil. Poult Sci. 2010;89(7):1530-6.
29. Barza M, Travers K. Excess infections due to antimicrobial resistance: the "Attributable Fraction." Clin Infect Dis. 2002;34(Suppl3): S126-30.

30. Martin LJ, Fyfe M, Doré K, Buxton J, Pollari F, Henry B, et al. Increased burden of illness associated with antimicrobial-resistant Salmonella enterica serotype Typhimurium infections. J Infect Dis. 2004;189(3):377-84

31. Ministério da Saúde, Agência Nacional de Vigilância Sanitária. Resolução RDC 12, de 2 de janeiro de 2001. Regulamento técnico sobre os padrões microbiológicos para alimentos. Brasilia: Ministério da Saúde, Agência Nacional de Vigilância Sanitária; 2001. Available from: http://www.anvisa.gov.br/ legis/resol/12_01rdc.htm Accessed 27 January 2011.

32. Ministério da Saúde, Agência Nacional de Vigilância Sanitária. Resolução RDC 13, de 2 de janeiro de 2001. Regulamento técnico para instruções de uso, preparo e conservação na rotulagem de carne de aves e seus miúdos crus, resfriados ou congelados. Brasilia: Ministério da Saúde, Agência Nacional de Vigilância Sanitária; 2001. Available from: http:// www.anvisa.gov.br/legis/resol/12_01rdc. htm Accessed 27 January 2011.

33. Ristori CA, Bergamini AMM, Rowlands REG Lopes GISL, de Paula AMR, de Oliveira MA, et al. Quantificação de Salmonella spp. e avaliação dos dizeres de rotulagem de carcaças de frango congeladas comercializadas no Estado de São Paulo. BEPA. 2008;5(52):16-9.

Manuscript received on 26 September 2011. Revised version accepted for publication on 31 October 2011.

RESUMEN Objetivo. Describir la prevalencia y la resistencia a los antibióticos de Salmonella spp. en canales de pollo congeladas de venta al por menor en 15 ciudades del Brasil. Métodos. Entre septiembre del 2004 y julio del 2006 se llevó a cabo un estudio descriptivo de los datos del Programa Nacional Brasileño de Vigilancia de la Prevalencia de la Resistencia Bacteriana en el Pollo (PREBAF). Durante el programa se recolectaron canales de pollo en 15 capitales estatales del Brasil, en las cinco regiones geográficas del país. Para aislar Salmonella spp. e identificar los serotipos, se usaron las técnicas convencionales. Para evaluar la resistencia frente a 18 antibióticos, se usó el método de la concentración inhibitoria mínima.

Resultados. En las 2679 canales de pollo examinadas, la prevalencia de Salmonella spp. fue de 2,7\% (amplitud, 0,0\%-8,9\%). El 50,6\% de las muestras positivas provinieron del estado de São Paulo. Se identificaron 18 serotipos. Los más frecuentes fueron Salmonella Enteritidis (48,8\%), Salmonella Infantis (7,6\%), Salmonella Typhimurium $(7,2 \%)$ y Salmonella Heidelberg $(6,4 \%)$. Las 250 cepas evaluadas fueron resistentes a uno o más antibióticos, y $133(53,2 \%)$ fueron multirresistentes ( $\geq 3$ clases de antibióticos). Salmonella Heidelberg fue resistente a la ceftriaxona $(75,0 \%)$ y al ceftiofur $(43,8 \%)$. Conclusiones. La prevalencia de Salmonella spp. en este estudio fue relativamente baja. Sin embargo, hubo una proporción elevada de cepas multirresistentes, inclusive a las cefalosporinas de tercera generación usadas para tratar la salmonelosis invasora. Los resultados confirman la relevancia del programa PREBAF, el cual se recomienda mejorar, por ejemplo, mediante un análisis oportuno de los datos. También es necesario revisar los límites permitidos de Salmonella spp. en el pollo que se vende al por menor en el Brasil.

Palabras clave Salmonella; farmacorresistencia microbiana; pollos; microbiología de alimentos; vigilancia sanitaria; Brasil. 